\title{
Non-Performing Assets of IDBI banks in India
}

\author{
Hoorunnisa ${ }^{1}$ and Prof. B. Bhagavan Reddy ${ }^{2}$
}

\author{
${ }^{1}$ Research Scholar, Dept. of Commerce, Rayalaseema University, Kurnool, \\ Andhra Pradesh, India and Gurunanak First grade Degree College, Bidar, Karnataka, India \\ ${ }^{2}$ Ex Principal \& Dean, Faculty of Commerce \& Management, Sri Venkateswara University, \\ Tirupati, Andhra Pradesh, India
}

\begin{abstract}
Banking industry is one of the basic instruments of economic growth. It should be on a sound footing as it constitutes an important link in various socioeconomic activities The failure of the banking sector in any country may have an adverse impact on other sectors. In India, non- performing assets (NPAs), are one of the major concerns in the financial system in general and banking sector in particular. The assets which do not perform any role in getting profit are called NPAs. The more the NPAs the lower the performance of any financial institution. The gross and net NPA has shown an increasing upward trend, but the total advances and net profits have decreased over the years. The secondary data from the published sources were used for analysed through statistical tools such as ratio, percentage and average. Keywords: loan assets, NPAS, sub-standard assets, doubtful assets, loss assets
\end{abstract}

\section{Introduction Concept of NPA}

The NPA relates to loans, advances and so on of a financial institution. As long as an asset generates expected income and does not disclose any unusual risk other than normal commercial risk, it is treated as performing asset. When it fails to generate the expected income, it becomes NPA. In other words, an asset becomes NPA when it ceases to generate income, dues for more than 90 days. A NPA is an advance where payment of interest or repayment of installments on principal or both remains unpaid for a stipulated period. IDBI Bank's commercial banking operations are divided into two areas: corporate banking and retail banking. The gross bad loans of the bank stood at Rs. 55, 558.26 crore in March 2018 as against Rs. 44, 752.59 crore on March 2017. The gross NPA ratio was increased to $1.43 \%$ to $32.42 \%$ from March 2009 to March 2018. The increase phenomena of NPA affects the interest income of the bank and adverse affect on net interest margin and thereby reduced the competitiveness of the IDBI bank.

\subsection{Classification of assets:}

Assets are classified into standard and NPAs. A standard asset is a performing asset. Standard asset generates continuous income and repayments as and when they fall due. Such assets carry a normal risk and are not NPA in the real sense. The NPAs are categorized into sub- standard, doubtful and loss. A substandard asset would be one, which has remained as NPA for a period less than or equal to 12 months. Such an assets will have defined credit weaknesses that jeopardize the liquidation of debt. This is characterized by the distinct possibility that the banks will sustain some loss, if deficiencies, are not corrected. Doubtful asset is one which remains in the sub - standard category for period of more than 12 months. A loan classified as doubtful has all the weaknesses inherent in assets that were classified as substandard, with the added characteristic that the weaknesses make collection or liquidation in full, on the basis of currently known facts, conditions and values-highly questionable and improbable. All those assets which cannot be recovered are loss assets. A loss asset is one where loss has been identified by the bank or internal or external auditors or the RBI inspection team but the amount has not been written off wholly. In other words, such an asset is considered uncollectable and of such little value that its continuance as a bankable asset is not warranted although there may be some salvage or recovery value.

\subsection{Significance of the study}

The IDBI bank formed an NPA management group comprises 200 odd officers deals with the NPA accounts on Pan-India basis and created credit monitoring group to reduce fresh NPA's. Due faulty 
lending practice, the researchers have made to analyze the NPA's of IDBI bank from 2009-2018.

\section{Review of Literature:}

A considerable account of research has been carried out in relation to NPAs of banks by academicians, researchers, policy- makers etc. The literature is available in the form of reports of various committees, commissions, study and working groups constituted by governments, RBI, economic analysts and researchers etc.

Kaveri (2001) studied the NPAs of several banks and suggested strategies to reduce the extent of NPAs. Jaynal Ud-din Ahmed (2011) has concluded that the earning capacity and profitability of banks had adversely affected by the incidence of high level of NPAs. The reduction of NPAs in banks poses a biggest challenge.

Sandeep and Parul Mital (2012) have analysed the comparative position of NPAs of select public and private sector banks. It is found that level of nonperforming asset both gross and net is on an average in upward trend all the nationalized banks but the growth rate is different. Banks got different ranks on the basis of mean and final ranking was done on the basis of average gross NPA rank and net NPA rank.

Vivek srivastava,Deepak bansal (2012) study on “A study of trends of non-performing assets in private banks in India" to find out whether there is positive trend and control of $\mathrm{NPA}^{\text {ee }} \mathrm{S}$ by the private sector banks in India for a period of five years from 20072012 and analysed by average and comparative percentage analysis. It was found that that the level of NPAS is alarming with public sector banks in India but there is slight improvement in the asset quality reflected by decline in the NPA percentage.

Zahoor Ahmed and M. Jagadeeshwaran, (2013) had summed up that NPA is a major problem and hurdle faced by the banking industry. And also highlighted the causes like wiiful default, improper processing of loan proposals, poor monitoring and follow up and so on. Thus there are many studies on the NPAs of banks. The specific studies on IDBI banks are scant in the literature. The studies on RRBs after merger/amalgamation are almost nil.

Jai Prakash Tripathi (2016) stated on "A Comparative Study: NPA's in Indian Banking Industry" It is found on the premise of examination of information that the advantage nature of open part banks and private segment banks enhanced reliably in the previous couple of years as reflected in the decrease in the proportion i.e. NPAs as rate of advances to weaker areas from $18.9 \%$ to 3 percent if there should be an occurrence of open part banks and from 12.15 percent to 0.5 percent

\section{Objectives of the study}

To examine the level of NPA of IDBI bank

To analyze the Segregation of Gross NPAs of the IDBI Bank

To examine the year-wise provision for Gross NPAs in the IDBI Bank

\section{Research methodology}

The analysis of data is the core part of research study, an attempt has been made to measure, evaluate and compare the performance of IDBI bank in view of NPA. Scientific methods were adopted nowadays to get the output or study made authentic and suffice to the purpose for which the study is meant for. The study focused for the period of 10 years i.e. from the year 2009-2010 to 2017-2018.

\subsection{Limitation of the study}

The extent of study is limited to IDBI Bank

The data collected for the period of 10 years of NPAs5

\section{Analysis and Result}

The ratio analysis was applied to analyze and compare the trends in banking business and finanacial performance. The secondary data were processed, to obtain the relevant results, the data has been tabulated, analysed and interpreted with the help of appropriate statistical tools like averages, coefficient of variation (C.V.), compound annual growth rate (CAGR), coefficient of correlation and ttest.

\subsection{Non-performing assets}

The assets of the IDBI banks are classified into two broad groups such as performing and non performing as shown in the Table 1 . The performing assets were Rs. 171453.36 crore in 2009 and gradually raised to Rs. 359728.74 crore in 2016 and subsequently declined. These were Rs. 336562.10 crore and Rs.321648.50 crore in 2017 and 2018 
respectively. In the total assets, the share of performing assets is 99.45 per cent in 2009 while the rest, 0.55 per cent is NPAs. By 2018, the proportion of the former has come down to the lowest at 91.82 per cent whereas the remaining, 8.18 per cent is NPAs. In terms of mean, the former accounts for 97.06 per cent whilst the proportion of latter is 2.94 per cent. It may be summed up that there is a decline in the account of performing assets in 2018 over
2009. A contrary picture emerges in the share of NPAs. The inconsistency is greater in the net NPAs when compared to performing assets. The growth is significant in the performing assets only. More than 95 per cent of assets are performing assets and the rest, NPAs. The growth in absolute and relative terms is alarming in the latter during the period under reference.

Table 1: Assets of the IDBI Bank during 2009-18

(Rs. crores)

\begin{tabular}{|c|c|c|c|c|}
\hline Year & Performing assets & NPAs & $\begin{array}{c}\% \text { of col. } 2 \text { to } \\
\text { total }\end{array}$ & $\begin{array}{c}\% \text { of col. } 3 \text { to } \\
\text { total }\end{array}$ \\
\hline (1) & (2) & (3) & (4) & (5) \\
\hline 2009 & 171453.36 & 948.96 & 99.45 & 0.55 \\
\hline 2010 & 232153.61 & 1418.41 & 99.39 & 0.61 \\
\hline 2011 & 251698.88 & 1677.91 & 99.34 & 0.66 \\
\hline 2012 & 287926.31 & 2910.93 & 99 & 1 \\
\hline 2013 & 319668.15 & 3100.36 & 99.04 & 0.96 \\
\hline 2014 & 324094.33 & 4902.3 & 98.51 & 1.49 \\
\hline 2015 & 350038.05 & 5992.52 & 98.32 & 1.68 \\
\hline 2016 & 359728.74 & 14643.39 & 96.09 & 3.91 \\
\hline 2017 & 336562.1 & 25205.8 & 93.03 & 6.97 \\
\hline 2018 & 321648.5 & 28665.14 & 91.82 & 8.18 \\
\hline Mean & 295497.2 & 8946.57 & 97.06 & 2.94 \\
\hline SD & 59858.67 & 10299.93 & & \\
\hline $\mathrm{CV}(\%)$ & 20.26 & 115.13 & & \\
\hline CAGR $(\%)$ & 6.49 & 40.61 & & \\
\hline $\mathrm{t}$-cal & $15.60 *$ & $2.71 \mathrm{NS}$ & & \\
\hline
\end{tabular}

Notes: * Indicates significant at 1 per cent level.

NS: Not significant

Source: Relevant issues of the IDBI Bank, Annual Report, Mumbai.

\subsection{Segregation of gross NPAs}

As per the prudential norms, gross NPAs in the IDBI Bank are furnished in the Table 2. The gross NPAs are divided into sub-standard gross NPAs, doubtful gross NPAs and loss gross NPAs. The sub-standard gross NPAs were Rs. 543.42 crore or 37.85 per cent in 2009 vis-a-vis Rs. 13234.38 crore or 23.81 per cent in 2018. There are ups and downs in both the percentage and absolute figures. The doubtful gross NPAs were Rs.856.73 crore or 59.67 per cent in 2009 as compared to Rs. 41015.87 crore or 73.79 per cent in 2018. In the mean time, there is continuous increase in absolute terms. But there are ups and downs in relative terms. The loss gross NPAs were Rs. 35.54 crores or 2.48 per cent in 2009 as compared to Rs. 1338.01 crores or 2.41 per cent during 2018. The fluctuations exist in both the absolute and percentage figures. On an average, per year, the share of sub-standard gross NPAs in the total gross NPAs is 26.27 per cent, doubtful gross NPAs 71.04 per cent and loss gross NPAs 2.69 per cent. The CV in these is 116.70 per cent, 124.18 per cent and 126.42 per cent serially. The CAGR is 37.61 per cent in sub-standard gross NPAs, 47.23 per cent in doubtful gross NPAs and 43.74 per cent in loss gross NPAs. These growth rates are insignificant. It may be summed up that there is an increase in the 
share of doubtful gross NPAs in 2018 over 2009. A contrary situation prevails in the proportion of substandard gross NPAs and loss gross NPAs in the same period. Further, more than 70 per cent of gross NPAs are in the form of doubtful gross NPAs. Despite an increase in all the kinds of gross NPAs in absolute figures, there are fluctuations in percentage terms. The inconsistency is lesser in the sub-standard gross NPAs relative to doubtful gross NPAs and loss gross NPAs. The growth in these gross NPAs is not significant at one per cent level. The increase in the proportion of doubtful gross NPAs as against a decline in the sub-standard gross NPAs is a matter of serious concern. The share of loss gross NPAs is almost static. The reason is that the borrowed accounts have moved from sub-standard category to doubtful category. This may have adverse impact on the financial strength of the Bank. The decline in the sub stand gross NPA is unfavourable to the Bank.

Table 2: Segregation of Gross NPAs of the IDBI Bank for the period 2009-18

\begin{tabular}{|c|c|c|c|}
\hline Year & Sub-standard & Doubtful & Loss \\
\hline 2009 & $\begin{array}{r}543.42 \\
(37.85) \\
\end{array}$ & $\begin{array}{r}856.73 \\
(59.67) \\
\end{array}$ & $\begin{array}{l}35.54 \\
(2.48) \\
\end{array}$ \\
\hline 2010 & $\begin{array}{l}1202.25 \\
(55.65) \\
\end{array}$ & $\begin{array}{l}928.61 \\
(42.98) \\
\end{array}$ & $\begin{array}{l}29.53 \\
(1.37) \\
\end{array}$ \\
\hline 2011 & $\begin{array}{c}1595.18 \\
(57.28) \\
\end{array}$ & $\begin{array}{c}1086.31 \\
(39.01) \\
\end{array}$ & $\begin{array}{l}103.24 \\
(3.71) \\
\end{array}$ \\
\hline 2012 & $\begin{array}{c}2449.88 \\
(53.83)\end{array}$ & $\begin{array}{c}1981.38 \\
(43.53)\end{array}$ & $\begin{array}{l}120.11 \\
(2.64)\end{array}$ \\
\hline 2013 & $\begin{array}{c}2144.45 \\
(33.25)\end{array}$ & $\begin{array}{c}4108.76 \\
(63.70)\end{array}$ & $\begin{array}{r}196.77 \\
(3.05)\end{array}$ \\
\hline 2014 & $\begin{array}{c}29015.20 \\
(29.13)\end{array}$ & $\begin{array}{c}67241.88 \\
(67.51)\end{array}$ & $\begin{array}{r}3344.51 \\
(3.36)\end{array}$ \\
\hline 2015 & $\begin{array}{c}30200.22 \\
(23.81)\end{array}$ & $\begin{array}{c}93596.23 \\
(73.79)\end{array}$ & $\begin{array}{r}3053.27 \\
(2.41)\end{array}$ \\
\hline 2016 & $\begin{array}{c}5922.23 \\
(23.81)\end{array}$ & $\begin{array}{c}18354.10 \\
(73.79)\end{array}$ & $\begin{array}{r}598.74 \\
(2.41)\end{array}$ \\
\hline 2017 & $\begin{array}{c}10654.64 \\
(23.81)\end{array}$ & $\begin{array}{c}33020.76 \\
(73.79)\end{array}$ & $\begin{array}{r}1077.19 \\
(2.41)\end{array}$ \\
\hline 2018 & $\begin{array}{c}13234.38 \\
(23.81) \\
\end{array}$ & $\begin{array}{c}41015.87 \\
(73.79) \\
\end{array}$ & $\begin{array}{r}1338.01 \\
(2.41) \\
\end{array}$ \\
\hline Mean & $\begin{array}{c}9696.18 \\
(26.27) \\
\end{array}$ & $\begin{array}{c}26219.06 \\
(71.04) \\
\end{array}$ & $\begin{array}{c}989.69 \\
(2.69) \\
\end{array}$ \\
\hline SD & 11315.69 & 32558.43 & 1251.15 \\
\hline $\mathrm{CV}(\%)$ & 116.70 & 124.18 & 126.42 \\
\hline CAGR (\%) & 37.61 & 47.23 & 43.74 \\
\hline t-cal & $2.68 \mathrm{NS}$ & $2.53 \mathrm{NS}$ & $2.20 \mathrm{NS}$ \\
\hline
\end{tabular}

Notes: Figures in brackets indicate the percentage to total.

NS: Not significant.

Source: Relevant issues of the IDBI Bank, Annual Report, Mumbai. 
5.3 Progress of Gross NPAs in the IDBI Bank during 2009-18

The gross NPAs in the IDBI Bank are shown in the Table 3 . A look at the Table reveals that the gross NPAs were Rs. 1435.69 crore in 2009 as against the highest at Rs.55588.26 crore in 2018. There is a gradual growth in the entire period. On an average, per year, gross NPAs are RS.16521.22 crore. The $\mathrm{CV}$ is 116.23 per cent. The CAGR is 44.14 per cent, which is not significant. The trend value reveals the extent of variation in the growth of gross NPAs in the subsequent period over the base year. The variation is between 148.32 per cent and 883.55 per cent during 2009-15. The fluctuation is 1732.62 per cent, 3117.15 per cent and 3871.88 per cent during 2016, 2017 and 2018 respectively. There are changes in the yearly increment. There is no decline in any one of the years over the previous year. The variation in the yearly increase is in the order of 24.21-96.10 per cent. The share of gross NPAs to total advances is 1.39 per cent in 2009 as compared to 32.37 per cent in 2018. The rate of increase is progressive throughout the period. In terms of mean, the proportion of gross NPAs to total advances outstanding is 9.38 per cent. It may be concluded that there is a gradual growth in the gross NPAs during the period. The raise in 2016, 2017 and 2018 is remarkable. The inconsistency is more than 100 per cent. The progress is alarming in the share of gross NPAs to aggregate advances over the study period. This is a matter of serious concern to all who have interest in the well being of the nation in general and the IDBI Bank is particular. There is a continuous increase in the trend value as well

Table 3: Progress of Gross NPAs in the IDBI Bank during 2009-18

\begin{tabular}{|c|c|c|c|c|}
\hline Year & Amount & Trend (\%) & $\begin{array}{c}\text { \% of change over previous } \\
\text { year }\end{array}$ & $\begin{array}{c}\text { Share of col. 2 to } \\
\text { advances (\%) }\end{array}$ \\
\hline 2009 & 1435.69 & 100.00 & - & 1.39 \\
\hline 2010 & 2129.38 & 148.32 & 48.32 & 1.54 \\
\hline 2011 & 2784.73 & 317.02 & 30.78 & 1.77 \\
\hline 2012 & 4551.37 & 317.02 & 63.44 & 2.51 \\
\hline 2013 & 6449.98 & 449.26 & 41.72 & 3.29 \\
\hline 2014 & 9960.16 & 693.75 & 54.42 & 5.04 \\
\hline 2015 & $12,684.97$ & 883.55 & 27.36 & 11.52 \\
\hline 2016 & 24875.07 & 1732.62 & 96.10 & 23.45 \\
\hline 2017 & 44752.59 & 3117.15 & 79.91 & 9.38 \\
\hline 2018 & 55588.26 & 3871.88 & 24.21 & \\
\hline Mean & 16521.22 & & & \\
\hline SD & 19203.27 & & & \\
\hline CV $(\%)$ & 116.23 & & & \\
\hline CAGR $(\%)$ & 44.14 & & & \\
\hline t-cal & $2.70 \mathrm{NS}$ & & & \\
\hline
\end{tabular}

\subsection{Provision for gross NPAs}

Every year, financial institutions and banks have an obligation to create a provision towards gross NPAs. The provision for gross NPAs is presented in the Table 4. It can be observed from the Table that the provision created for gross NPAs was Rs. 119.05 crore in 2009. This has progressively increased to Rs. 19126.14 crore in 2018. On an average, per year, the provision stood at Rs. 4062.90 crore. The $\mathrm{CV}$ is
155.67 per cent. The CAGR is 66.18 per cent, which is insignificant. The share of provision for gross NPAs to gross NPAs is 8.29 per cent in 2009. It has gone up to the highest at 34.41 per cent with ups and downs during 2018. In the mean while, the fluctuations are noticeable. In terms of mean, the proportion of provision for gross NPAs in the gross NPAs is 19.74 per cent. It may be summed up that there is a growth in 
Table 4: Year-Wise Provision for Gross NPAs in the IDBI Bank during 2009-18

(Rs. crores)

\begin{tabular}{|c|c|c|c|}
\hline Year & Gross NPAs & Provision & \% of col. (3) to col. (2) \\
\hline 2009 & 1435.69 & 119.05 & 8.29 \\
\hline 2010 & 2129.38 & 236.34 & 11.10 \\
\hline 2011 & 2784.73 & 371.58 & 13.34 \\
\hline 2012 & 4551.37 & 645.54 & 14.18 \\
\hline 2013 & 6449.98 & 1612.94 & 25.01 \\
\hline 2014 & 9960.16 & 1618.3 & 16.25 \\
\hline 2015 & 12684.97 & 1622.86 & 12.79 \\
\hline 2016 & 24875.07 & 3507.11 & 14.10 \\
\hline 2017 & 44752.59 & 11769.1 & 26.30 \\
\hline 2018 & 55588.26 & 19126.14 & 34.41 \\
\hline Mean & 16521.22 & 4062.90 & 19.74 \\
\hline SD & 19203.27 & 6324.81 & \\
\hline CV $(\%)$ & 116.23 & 155.67 & \\
\hline CAGR $(\%)$ & 44.14 & 66.18 & \\
\hline t-cal & $2.7 \mathrm{NS}$ & $1.97 \mathrm{NS}$ & \\
\hline
\end{tabular}

Note: NS: Not significant.

Source: Relevant issues of the IDBI Bank, Annual Report, Mumbai.

the provision for gross NPAs during the period. The progress in the provision for gross NPAs is more than that of the growth in the gross NPAs. The CV in the former is greater than that of the latter. The gross NPAs have gone up due to increase in the provision for gross NPAs. The increased provision reflects that there is erosion in the quality of assets in the recent past when compared to the earlier period. On an average, per year, the share of provision for gross NPAs in the gross NPAs is less than 20 per cent. This 20 per cent is considered as abnormal. This reflects the erosion in the quality of gross NPAs in the study period.

Table 5: Movement in the Net NPAs in the IDBI Bank for the period 2009-18

\begin{tabular}{|c|c|c|c|c|c|}
\hline Year & Opening balance & $\begin{array}{c}\text { Addition during } \\
\text { the year }\end{array}$ & Total & $\begin{array}{c}\text { Reduction } \\
\text { during the year }\end{array}$ & $\begin{array}{c}\text { Closing } \\
\text { balance }\end{array}$ \\
\hline 2009 & 925.24 & 534.45 & 1459.69 & 510.73 & 948.96 \\
\hline 2010 & 948.96 & 734.71 & 1683.67 & 277.35 & 1406.32 \\
\hline 2011 & 1406.32 & 560.42 & 1966.74 & 288.83 & 1677.91 \\
\hline 2012 & 1677.91 & 1485.09 & 3163.00 & 252.07 & 2910.93 \\
\hline 2013 & 2910.93 & 562.43 & 3473.36 & 373.00 & 3100.36 \\
\hline 2014 & 3100.36 & 2383.25 & 5483.61 & 581.31 & 4902.3 \\
\hline 2015 & 4902.3 & 1792.97 & 6695.27 & 702.75 & 5992.52 \\
\hline 2016 & 5992.52 & 9797.27 & 15789.79 & 1146.4 & 14643.39 \\
\hline 2017 & 14643.39 & 12160.93 & 26804.32 & 1598.52 & 25205.8 \\
\hline 2018 & 25205.8 & 10595.16 & 35800.96 & 7135.82 & 28665.14 \\
\hline
\end{tabular}

Source: Relevant issues of the IDBI Bank, Annual Report, Mumbai.

\subsection{Movement in net NPAs}

The movement in the net NPAs is presented in the Table 5. It can be observed from the Table that the movement in the net NPAs is quite alarming. The balance of net NPAs at the end of each year has gone up in the entire period. The addition to net NPAs was Rs. 534.45 crore in 2009 while Rs. 10595.16 crore in 2018. In the mean time, there are to and fro changes. 
The year 2017 has registered the highest at Rs. 12160.93 crore. The reduction from net NPAs was Rs.510.73 crore in 2009 as compared to the highest at Rs. 7135.82 crore in 2018. The year 2012 has reported the lowest at Rs. 252.07 crore. The closing balance has gone up year after year due to the faster growth in the addition to net NPAs as compared to reduction from net NPAs. The gap between the addition to and reduction from net NPAs shows the recovery efficiency of the Bank. It may be concluded that the movement in net NPAs is unfavorable from view point of the Bank. This is an account of higher addition to net NPAs as compared to lesser reduction from net NPAs during the period. In other words, the recovery from NPAs is relatively low in the recent past. The reasons are as follows. The Bank might not have made concerted efforts to collect the dues from the existing default account as desired by the government and the RBI. The Bank has collected lesser amount from net NPAs while added heavy amount to net NPAs during the study period.

Table: 6 Write Off and Upgraded Gross NPAs from Total Gross NPAs in the IDBI Bank during 2009-18

\begin{tabular}{|c|c|c|c|c|}
\hline Year & Up-gradation & Write offs & \% of col. 2 to total & \% of col. 3 to total \\
\hline 2009 & NA & NA & - & - \\
\hline 2010 & 33.78 & 476.94 & 6.61 & 93.39 \\
\hline 2011 & 277.42 & 883.57 & 23.90 & 76.10 \\
\hline 2012 & 419.47 & 319.43 & 56.77 & 63.23 \\
\hline 2013 & 207.29 & 382.65 & 35.14 & 97.43 \\
\hline 2014 & 36.79 & 1392.68 & 2.57 & 90.66 \\
\hline 2015 & 607.95 & 1608.85 & 27.42 & 45.50 \\
\hline 2016 & 562.75 & 5459.43 & 54.34 & 60.53 \\
\hline 2017 & 3435.82 & 2868.2 & 39.47 & 65.34 \\
\hline 2018 & 8160.93 & 12514.78 & 34.66 & \\
\hline Mean & 1526.91 & 2878.50 & & \\
\hline SD & 2702.01 & 2702.01 & & \\
\hline CV $(\%)$ & 176.96 & 137.80 & & \\
\hline CAGR $(\%)$ & 73.10 & 38.64 & & \\
\hline t-cal & $1.56 \mathrm{NS}$ & $2.09 \mathrm{NS}$ & & \\
\hline
\end{tabular}

Notes: NA: Not available NS: Not significant

Source: Relevant issues of the IDBI Bank, Annual Report, Mumbai.

\subsection{Recovery}

The amount recovered from gross NPAs is depicted in the Table 7. A look at the Table shows that the amount recovered from gross NPAs has increased from Rs. 278.77 crore in 2010 to Rs.6839.72 crore in 2018. In the mean while, the variations are considerable. The mean in the recovery is Rs. 1312.07 crore. The share of recovery to gross NPAs is 13.09 per cent in 2010 as against 12.30 per cent in 2018. On an average, per year, the proportion of recovery from gross NPAs to aggregate gross NPAs is 7.94 per cent. The $\mathrm{CV}$ in the amount recovered from gross NPAs in 162.02 per cent. The CAGR is 37.71 per cent, which is not significant. It may be summed up that there is a decline in the share of amount recovered from gross NPAs to gross NPAs in 2018 over 2010. The CV in the amount recovered is higher when compared to gross

NPAs. The progress is not significant in gross NPAs as well as amount recovered from gross NPAs. The amount recovered from gross NPAs to total gross NPAs, on an average, per year, is below 10 per cent. 
Table: 7 Recoveries from Gross NPAs in the IDBI Bank during 2009-18

\begin{tabular}{|c|c|c|c|}
\hline Year & Gross NPAs & Amount recovered @ & \% of col. (3) to col. (2) \\
\hline 2009 & 1435.69 & NA & - \\
\hline 2010 & 2129.38 & 278.77 & 6.14 \\
\hline 2011 & 2784.73 & 170.98 & 1.20 \\
\hline 2012 & 4551.37 & 54.70 & 3.89 \\
\hline 2013 & 6449.98 & 251.14 & 7.69 \\
\hline 2014 & 9960.16 & 766.35 & 9.14 \\
\hline 2015 & 12684.97 & 1159.19 & 3.51 \\
\hline 2016 & 24875.07 & 874.33 & 3.16 \\
\hline 2017 & 44752.59 & 1413.48 & 12.30 \\
\hline 2018 & 55588.26 & 6839.72 & 7.94 \\
\hline Mean & 16521.22 & 1312.07 & \\
\hline SD & 19203.27 & 2125.86 & \\
\hline CV $(\%)$ & 116.23 & 162.02 & \\
\hline CAGR $(\%)$ & 44.14 & 37.71 & \\
\hline t-cal & $2.70 \mathrm{NS}$ & $1.68 \mathrm{NS}$ & \\
\hline
\end{tabular}

Notes: @ Includes aggregate of gross NPAs and additions to during the year

NS: Not significant

Source: Relevant issues of the IDBI Bank, Annual Report, Mumbai.

\section{Conclusion}

Gross NPA ratio has progressively increased from 8.29 per cent in 2009 to 25.01 per cent in 2013 with relative ups and downs during 2014-18. On the other hand, net NPAs have just increased, from Rs.948.96crore in 2009 to Rs.28665.14 crore in 2018. The doubtful debts have increased as against sub - standard assets. This is not favorable to the bank. The loss assets were present in all years. There is no marked improvement in the asset profile of the IDBI. It is held that the recoveries are due mainly from sub - standard and doubtful categories and not from the loss category. It may be concluded that the amount collected from NPAs was higher in 2018 when compared to 2012. There is no up gradation during 2009. A comprehensive recovery frame work is the need of the hour, the introduction of insolvency and bankruptcy code would be supportive to resolve the stressed corporate loans in timely manner. Effective utilization of DRTs ( debt recovery tribunal) SARFAESI (Securitization and reconstruction of financial assets and enforcement of security interest act 2002) and the RBIs latest framework on the resolution of stressed assets in February 2018 would help the bank to recover from the

NPA

\section{Acknowledgments}

We grateful to Director, Research studies, and Head of the department, Commerce department, Rayalaseema University, Kurnool to allow me as part-time research scholar. I am thankful to my guide Prof. B. Bhagavan Reddy, Ex- Principal and Dean, Faculty of Commerce \& Management, Sri Venkateswara University, Tirupati (A.P) for time to time help to complete the thesis.

\section{References}

[1] Kaveri, V. S. (2001), Prevention of NPA Suggested Strategies, Vinimaya, 23(8): 7-9.

[2] Sandeep (2012) Comparative study on npa management of nationalised banks, Indianresearchjournals, Vol.2 (8), pp. 66-78

[3] Vivek Srivastava1 Deepak Bansal (2012) “ A Study of trends of Non-Performing Assets in Private Banks in India" SHIV SHAKTI International Journal in Multidisciplinary and Academic Research (SSIJMAR) Vol. 2 (2).

[4] Zahoor Ahmed and Prof.Jegadeeshwaran.M. (2013) "Comparative Study on NPA Management of Nationalised Banks", International 
Journal of Marketing, Financial Services \& Management Research, Vol.2 (8) pp 66-78.

[5] Jai Prakash Tripathi (2016), Comparative Study: NPA's in Indian Banking Industry, IOSR-JBM, Volume 18 (10), pp.57-64

[6] Malyadri P. (2003), NPA's in Commercial Banks-An Overview, Banking Finance, Monthly, January 2003, Vol. (16), pp.6-9
[7] Samal, B. (2002), The NPA Overhung: Magnitude, Solution and Legal Reforms, Vinimaya, Vol.23 (3): 12-17

[8] IDBI. (1995). Report on Development Banking, 1993-94, Bombay, 74. 